\title{
DYNAMIC CHANGES IN THE LOWER GÁLLEGO RIVER (EBRO BASIN, NE SPAIN) AND THEIR RELATIONSHIP WITH ANTHROPIC ACTIVITIES AND THE QUATERNARY SUBSTRATE
}

\section{J.L. PEÑA-MONNÉ ${ }^{1 *}$, L.A. LONGARES ALADRÉN ${ }^{1}$, V. RUBIO FERNÁNDEZ², M.M. SAMPIETRO-VATTUONE ${ }^{3}$, M. SÁNCHEZ-FABRE ${ }^{1}$}

\author{
${ }^{1}$ Dpto. de Geografía y Ordenación del Territorio and IUCA, \\ Universidad de Zaragoza, 50009 Zaragoza, Spain. \\ ${ }^{2}$ Dpto. de Geografía, Universidad Autónoma de Madrid, 28049 Madrid, Spain. \\ ${ }^{3}$ Laboratorio de Geoarqueología, Universidad Nacional de Tucumán and CONICET,
}

Tucumán, Argentina.

\begin{abstract}
The lower Gállego River has been strongly degraded since the 1960s due to human activity (gravel mining, dump accumulation, channeling works), which has produced a deep channel incision. Although these humandriven processes are usually reported in fluvial bibliography, in this case, more complex results are observable. For instance, regarding the depth and incision rates, we observed no relationship between the most anthropically impacted areas and the sections with the deepest incisions; moreover, the deepening process continues 40 years after the human interventions ceased. The reason for this maladjustment is the role played by the exhumation of the underlying Pleistocene substrate, affected by the synsedimentary processes of karstification. The appearance of paleodolines filled with fine sediments on the incision bottom and sides is the main factor conditioning the continuity and magnitude of the process. Besides, these paleodepressions direct the river dynamics and course, thus favoring its widening when they appear and causing the development of a new riverbed (Qt13) while the 1960s floodplain (Qt12) is becoming an old terrace located between 5 and $11 \mathrm{~m}$ above the new alluvial bottom. There are no previous records about this kind of consequences in the regional fluvial dynamics.
\end{abstract}

Cambios dinámicos en el curso inferior del río Gállego (cuenca del Ebro, $\mathrm{NE}$ de España) y su relación con las actividades humanas y el sustrato cuaternario

RESUMEN. El curso bajo del río Gállego ha sido fuertemente degradado desde los años 1960 por la actividad antrópica (extracción de áridos, acumulaciones de escombros, obras de encauzamiento) que ha conducido a una fuerte incisión. Aunque este tipo de procesos inducidos por el hombre son 
habituales en la bibliografía fluvial, en este caso se aprecian efectos más complejos. Son, por ejemplo, la profundidad y velocidad de la incisión, la falta de relación entre puntos de máxima intervención y los de mayor incisión o la continuidad del proceso cuarenta años después de cesar ese tipo de acciones. La respuesta a estos desajustes está en el papel que está jugando la exhumación del sustrato pleistoceno infrayacente, afectado por procesos sinsedimentarios de karstificación. La aparición de paleodolinas rellenas de sedimentos finos en el fondo y laterales de la incisión es actualmente el principal determinante de su importancia y continuidad. Además, estas paleodepresiones dirigen la dinámica y trazado del río y puntualmente favorecen ensanchamientos laterales. Esto propicia la aparición de un nuevo lecho (Qt13) a medida que el lecho de los años 1960 (Qt12) va quedando como una terraza colgada entre 5 y $11 \mathrm{~m}$ sobre el nuevo fondo aluvial. No hay antecedentes de este tipo de consecuencias en la dinámica fluvial regional.

Key words: Fluvial terraces, fluvial dynamics, gravel mining, incision, paleodolines.

Palabras clave: terrazas fluviales, dinámica fluvial, minería de gravas, incisión, paleodolinas.

Received: 4 November 2019

Accepted: 6 December 2019

*Corresponding author: José Luis Peña Monné, Departamento de Geografía and IUCA, Universidad de Zaragoza, 50019 Zaragoza, Spain. E-mail address: jlpena@unizar.es

\section{Introduction}

The Ebro depression is located in the NE of the Iberian Peninsula. It is bordered by the mountainous reliefs of the Pyrenees (Aneto, $3040 \mathrm{~m}$ a.s.1.) and the Iberian Ranges (Moncayo, $2314 \mathrm{~m}$ a.s.1.) (Fig. 1a). It is crossed by the Ebro River and its tributaries from both mountain ranges. Among the most important tributaries are those from the Southern Pyrenees region, which during the Quaternary gave rise to the development of large alluvial plains, leaving large fluvial accumulations in the northern piedmont of the Ebro depression (Gutiérrez and Peña Monné, 1994). Inside this wide fluvial set, the Gállego River presents major problems for reconstructing the Quaternary fluvial terrace system. The headwaters of the Gállego River are in the Pyrenean massifs of Balaitús and Infiernos, which reach over $3000 \mathrm{~m}$ a.s.l. After traversing the Pyrenean structures, the lower section of the Gállego River flows across the Ebro depression until its confluence with the main river, close to the city of Zaragoza, at $220 \mathrm{~m}$ a.s.1. (Figs. 1a, 1b). The basin extends over $4009 \mathrm{~km}^{2}$, with $19.77 \mathrm{~m}^{3} / \mathrm{s}$ of annual middle flow (Ardisa), and the seasonal regime is pluvionival due to the snowmelt from the Pyrenean area during the spring. 


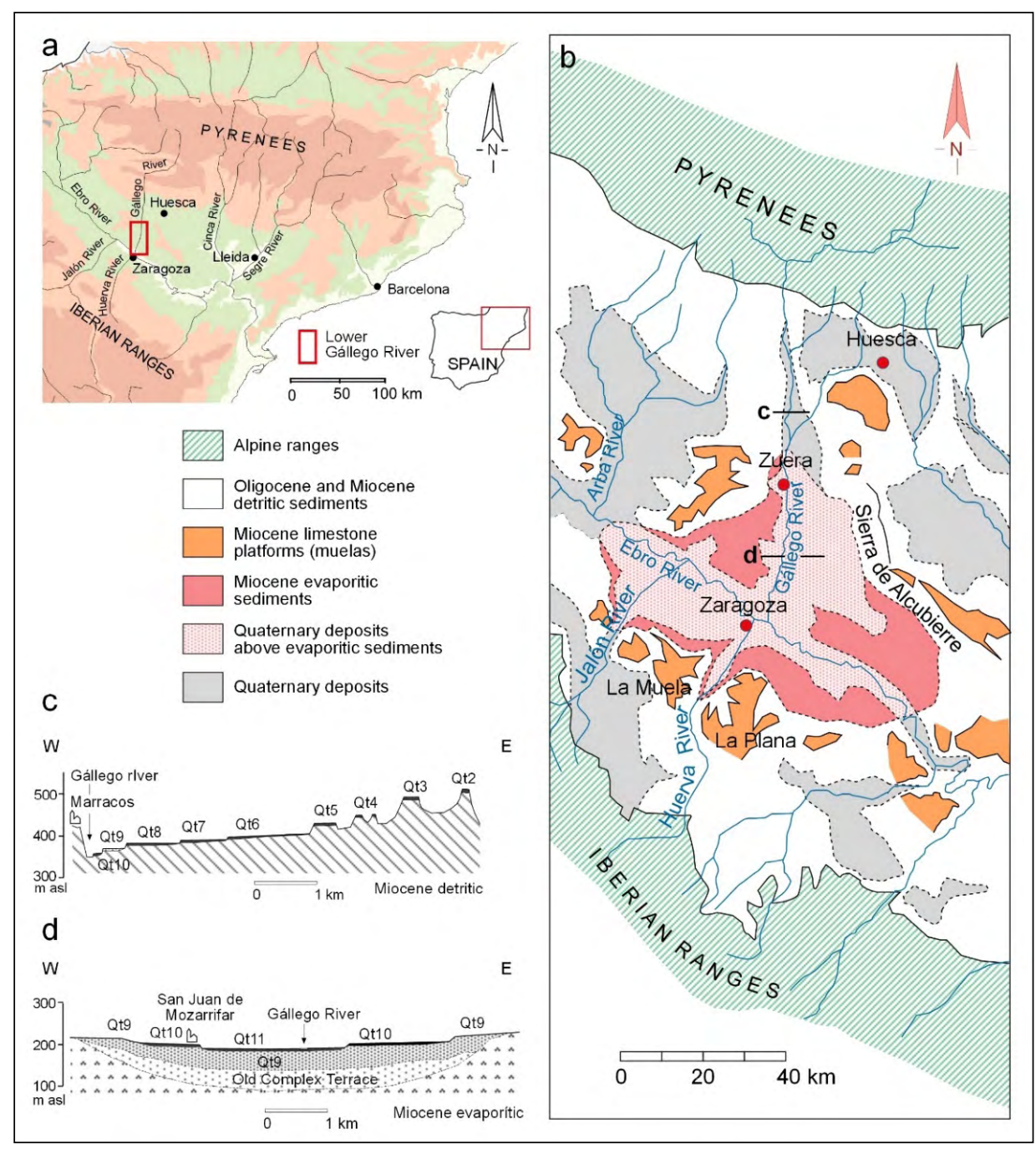

Figure 1. (a) Location maps; (b) area of Miocene evaporitic material on the central sector of the Ebro basin and its relationship with the Quaternary fluvial network; (c) cross section of the Quaternary terrace levels in the middle course of the Gállego River (Marracos), (d) cross section of the lower section of the Gállego River terrace levels (San Juan de Mozarrifar) (based on Benito et al., 2010). Profile locations are shown in (b).

Along the last $25 \mathrm{~km}$ before its confluence with the main river, the Gállego flows over Quaternary sediments deeply affected by the karstification of the underlying Miocene evaporitic formations, which are common around the center of the Ebro basin (Fig. 1b) (Benito et al., 1996, 1998, 2000). Karstification processes gave rise to the formation of paleodolines and the thickening of the fluvial terraces. These processes also affect 
the Ebro River terraces and other tributaries in the area (Guerrero et al., 2004, 2008; Luzón et al., 2008; Soriano et al., 2012). The dissolution of the evaporitic materials is still active (Gutiérrez et al., 1985), although they are more related to the influx of urban and industrial waters in the central section of the Ebro River, causing serious hazards (Soriano and Simón, 1995; Simón and Soriano, 2002; Lamelas, 2007; Gutiérrez et al., 2008).

At present, the most relevant hydrogeomorphological issue of the lower Gállego River is not karstification, but the occurrence of an increasing channel incision. Until recently, this tendency was related to a human-triggered process impacting over the basin and this river section (Marcos González, 1991; Martín Vide et al., 2010). The aims of our research were to re-analyze the anthropic impact on the river and study the influence of the Quaternary substrate on the characteristics of the incision. We also aimed to understand the new fluvial adaptive mechanisms and interpret their geomorphological consequences. Special attention was given to those fluvial sections where several factors are combined and lead to exceptional incision deepening rates and major changes in the morphohydrological dynamics, whose future evolution is difficult to predict.

\section{Regional settings}

The Ebro depression is a continental sedimentary basin generated as a foreland basin during the Pyrenean uplift in the Alpine orogeny. The Miocene sediments that filled its central sector are composed of evaporites sedimented in sulfated-chlorinated lacustrine environments (Ortí et al., 1989; Ortí, 1990). The sediments belong to the Zaragoza Fm., as defined by Quirantes (1978); more specifically they belong to the Upper Unit of Torrescusa and Klimowitz (1990) and can reach more than $500 \mathrm{~m}$ in thickness ("Gypsum of Zaragoza"). They are composed of interbedded clays, anhydrite, glauberite, and halite (Salvany et al., 2007; Guerrero et al., 2013), while the surface is formed of fibrous, purulent, and nodular gypsums, alabaster, etc. From a lithostructural point of view, the Zaragoza Fm. is located in the T4 Tectosedimentary Unit (UTS) of the Tertiary Ebro basin (Pardo et al., 2004). The evaporitic formations crop out some $25-30 \mathrm{~km}$ around the city of Zaragoza. Therefore, the lower Gállego River is inside these formations from the north of Zuera until its confluence with the Ebro River (Fig. 1b).

Since the Upper Miocene and since the basin opened to the Mediterranean (Urgeles et al., 2010), the Ebro and its tributaries have started a generalized erosion process by transferring Tertiary sediments to the sea. This erosive process affected mostly the evaporitic and fine detrital materials due to their minimal resistance. Harder lithologies, corresponding to the Miocene limestones from the center of the basin, were sculpted forming residual reliefs in high topographic positions (650-800 m a.s.1.) and structural platforms (muelas) (Gutiérrez and Peña-Monné, 1994). These reliefs are the water divides between valleys in the central area of the Ebro basin. The reliefs surrounding the Gállego River are Sierra de Alcubierre and Montes de Castejón (Fig. 1 b). 
Research on the Quaternary in the Gállego valley started to be conducted in the second half of the twentieth century (Bomer, 1957; 1978; Mensua and Ibáñez, 1977; Alberto et al., 1984). However, it was Benito (1989) who contributed to a deeper understanding of the fluvial terrace system and the interpretation of its sedimentary arrangement. At present, 12 strath terrace levels are recognized (Qt1 to Qt12, from oldest to youngest) along the middle and part of the lower Gállego River (Fig. 1c). The terrace system arrangement changes when the river reaches the Miocene gypsums, around $25 \mathrm{~km}$ before Zaragoza and starts a cut-and-fill or nested fill terrace disposition (Benito, 1989; Benito et al., 1996) (Fig. 1d). The geophysical and hydrogeological data recorded by Benito et al. (2000) show an alluvial fill of more than $100 \mathrm{~m}$ in thickness due to the superposition of terraces. Benito et al. (1998) established that the sediment of the oldest terraces (Qt2 to Qt4) was deposited before $780 \mathrm{ky}$ BP based on paleomagnetic reversals. I The first chronological data for the upper and middle sections of the river were determined by OSL was by Peña Monné et al. (2003, 2004), Sancho et al. (2004, 2008), and Lewis et al. (2009). Finally, Benito et al. (2010) continued with OSL studies of the main fluvial terraces along the lower river course.

In this lower section, Benito (1989) and Benito et al. (1996, 1998, 2000) indicated that there is a lower deformed unit (Old Complex Terraces), which includes several old terrace levels. They identified an upper group overlying this unit, including terrace Qt9 and later terraces (Fig. 1d). The Qt9 level reaches a minimum thickness of $28 \mathrm{~m}$ and is mainly composed of gravels. The level is highly deformed by synsedimentary karstification due to subsidence and collapses. Its age was established by OSL dating at around 150-160 ky BP in the upper and middle river course (Lewis et al., 2009) and between $147 \pm 16 \mathrm{ky} \mathrm{BP}$ and $181 \pm 13 \mathrm{ky}$ BP in the lower course (Benito et al., 2010). A new terrace level (Qt10) was sedimented discordantly over the Qt9 terrace (Fig. 2a). This new level is not affected by karstic deformations and it reaches 3-4 $\mathrm{m}$ in thickness. Its age was established by OSL at between $102 \pm 11$ y $124 \pm 13 \mathrm{ky} \mathrm{BP}$ (Benito et al., 2010). In the study area, this terrace is located 16-19 $\mathrm{m}$ above the present floodplain. After the Qt10 terrace formation, a new incision phase started and eroded much of this accumulation and even the underlying Qt9 terrace. A new floodplain developed corresponding to the Qt11 level and mostly supported by the Qt9 level (Fig. 2b). It was dated between $55.4 \pm 7.4 \mathrm{ky}$ BP (Benito et al., 2010) and its scarp reaches 8-10 $\mathrm{m}$ above the present floodplain. Benito et al. (2010) pointed out the formation of a new terrace dated to $16.8 \mathrm{ky} \mathrm{BP}$, to the north of the study area. As this accumulation has no continuity to the south, we will not take it into account in this paper.

After a new incision during the Holocene, the Qt12 terrace was formed (Fig. 2c). This terrace is usually located $1.5-2 \mathrm{~m}$ above the present floodplain and it is possible to see several meander scars in older aerial photographs, indicating the existence of a greater floodplain $(1927,1946)$. 


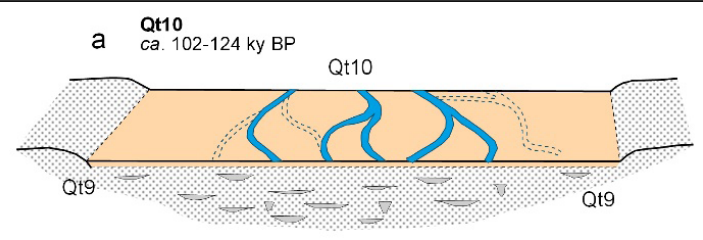

b Qt11

ca. 55 ky BP

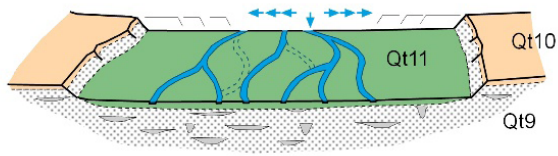

d $\quad 1960-1989$

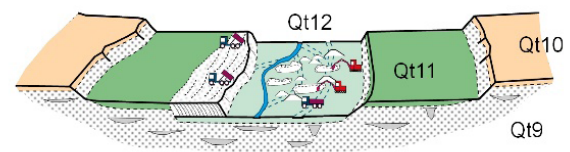

C $\quad$ Qt12

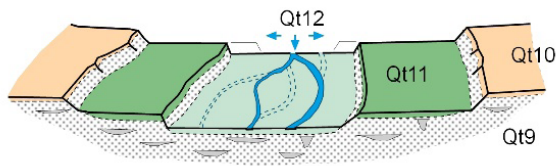

e 1996-present day

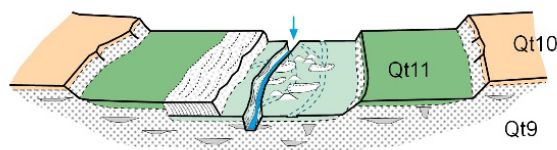

Figure 2. Evolutionary draws of the fluvial terraces of the Gállego River in the San Juan de

Mozarrifar section; (a) Qt10 terrace overlying the Qt9 level, where some synsedimentary paleodolines were represented; (c) new incision and Qt12 terrace formation; (d) evolution between 1960 and 1990 with gravel mining in the riverbed and lateral waste accumulations; (e) incision started in the 1996 flood with Qt9 paleodoline exposure. (OSL datings from Benito et al., 2010).

The present climate in the central Ebro basin is Continental Mediterranean with semiarid characteristics. The average annual rainfall is about $350 \mathrm{~mm}$ and the average annual temperature is $15^{\circ} \mathrm{C}$ (Cuadrat, 2004). The highwater deficit and intense deforestation due to overgrazing and agricultural occupation since prehistoric times (Peña-Monné et al., 2014, 2018) further intensify the arid landscape of the riverbanks of the Gállego River lower course.

\section{Methodology}

This study was initiated after a large flood produced an incision in January 1996. This flood exhumed several paleodolines in the riverbed of the Gállego River. Fieldwork subsequently recorded detailed information about the channel evolution together with a complete inventory of the karstic paleodepressions and the areas with paleopeats, rapid and pool formations, changes in river direction, lateral slides, and changes in the disposition of fluvial bars. These geomorphological effects were mapped using a GPS Garmin Montana 650. As a follow-up, conventional photographs were taken, and these were complemented in recent years with drone oblique images (DJI Phantom 4 and Mavic Pro) to obtain a better perspective.

Evolutionary cartography was performed in the lower course of the Gállego River by analyzing different dates using ArcGIS 10.5. The best information was recovered from aerial photographs taken in 1927 (Confederación Hidrográfica del Ebro), 
photogrammetric flights from 1946 and 1947 (Army Map Service, USA), national flights from 1979 and 1997, orthoimages from the PNOA series for 2004 and 2012 (Instituto Geográfico Nacional), and Google Earth images (2016-2018).

Intensive fieldwork was conducted between 2004-2005 when a map of the fluvial environment of the lower Gállego was prepared at a scale of 1:2000 for Zaragoza city hall (unpublished) and again in 2017-2018 to update the maps.

A detailed map was made of the area of La Lenteja because this section has experienced the greatest hydrogeomorphological changes. The procedure was performed to compare the geomorphological variations and land-use changes between 1927 and 2018. Stratigraphic descriptions of several paleodolines were recorded to establish the typical sequences. This was accompanied by a detailed analysis of the section with the highest incision rates and the evolution of channels and bars during and after floods. The hydrological information used in this paper is from Confederación Hidrográfica del Ebro (Ebro Water Authority) and Sistema de Información del Anuario de Aforos published by Ministerio para la Transición Ecológica (https://sig.mapama.gob.es/redes-seguimiento/).

\section{Results}

\subsection{The recent evolution of the Gállego River}

It was possible to reconstruct the recent evolution of the floodplain of the Gállego River from multi-temporal maps, aerial photographs, and orthoimages. Although the first detailed maps available date back to 1890 , when the topographic map of Casañal was made, the first document taken as reference for the recent evolution of the lower Gállego, was the aerial photographs taken by Confederación Hidrográfica del Ebro (1927), due to their high precision (Fig. 3a). These images show a wide riverbed course (500-800 m) with multiple channels and non-vegetated gravel bars. As there are no bank defenses, the river flows freely, forming a braided system. The lateral mobility of the channels is high because the sides are not cohesive, and it is possible to identify some abandoned channels. The bars are composed of gravel, and the fluvial plain shows large accumulations of fine material.

These characteristics are similar in the aerial photographs from 1946 and 1957 (Fig. 3b) and later (Figs. 3c, 3d). The progressive growth of the city of Zaragoza, the creation of the Polo de Desarrollo Industrial estate in 1960, and the construction of communication routes (roads and railway) completely changed the landscape of the last $10 \mathrm{~km}$ of the lower Gállego River course. These civil works required raw materials from the vicinity of Zaragoza, and therefore, gravel mining was conducted in the riverbed of the Gállego River. Meanwhile, large slag heaps were accumulated on the riverside (Fig. 3d). This anthropic impact was mainly concentrated on the Gállego and Ebro rivers, as shown by García Anquela et al. (1985) and Marcos González (1991). The changes were accompanied by defensive works, such as concrete dykes, gabions, rock breakwaters, and earth levees. These constructions created imposed constraints on the riverbed sides during the flood season. From the hydrogeomorphological point of view, all these fluvial intervention processes produced a progressive narrowing of the river channel and a loss of sinuosity. As Marqués (2018) points out on the final river section between San Juan 
de Mozarrifar and the Ebro River confluence, the river sinuosity decreased from 1.33 (1927) to 1.15 (2012). As a result, the river was almost totally channelized (Fig. 3e), affecting its morphological behavior and deteriorating this fluvial section.

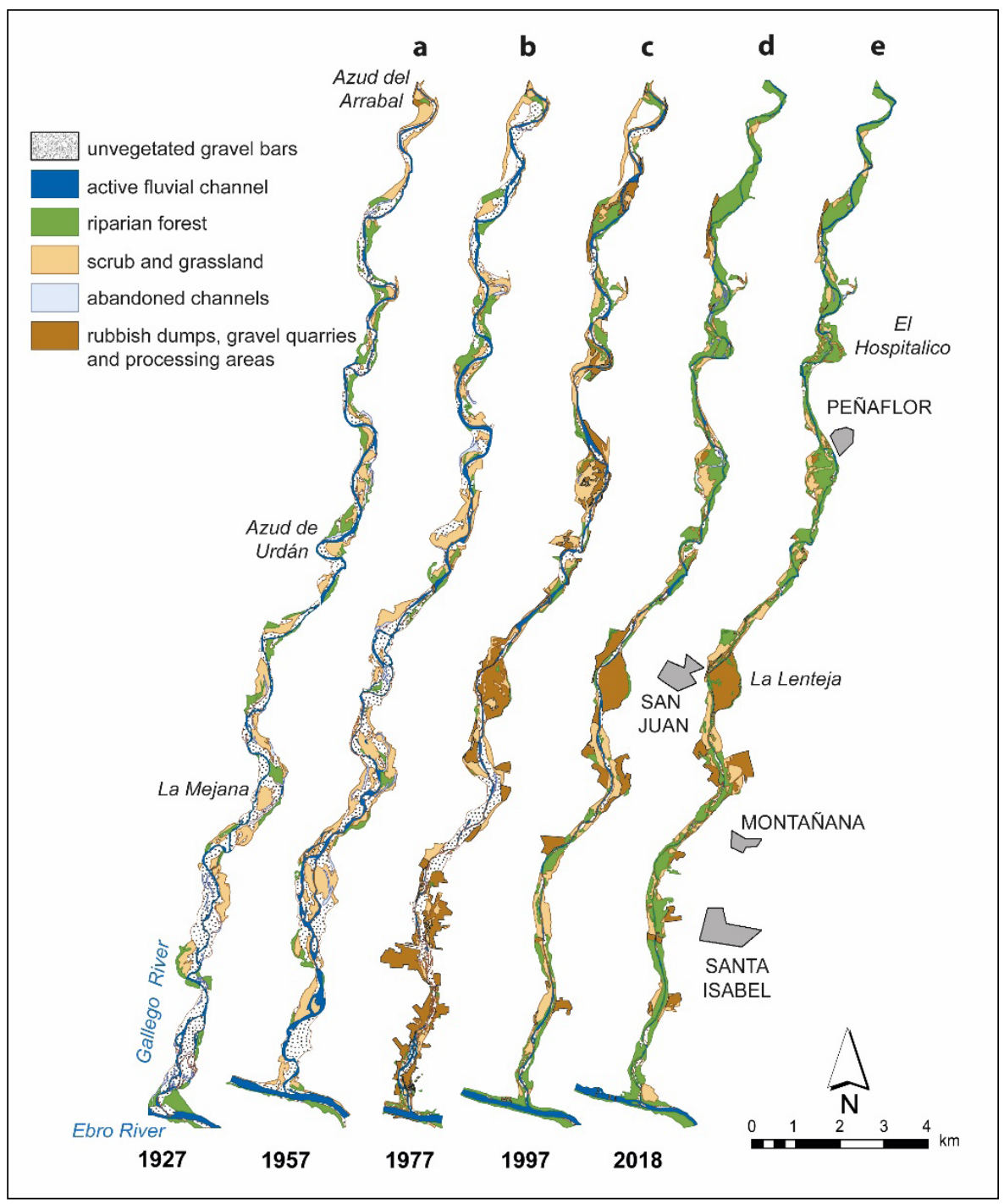

Figure 3. Five maps of the Gállego River (1927-2018) showing the changes produced in the lower Gállego between the Urdán azud and the Ebro River confluence.

The most interesting area in terms of geomorphology and human impact on the river channel is La Lenteja (Fig. 4), where a wide meander existed between 1927 and 1957, the concave part reaching the left side of the river (Fig. 4a). After the floods in the autumn-winter of 1959 and 
especially in June 1960 (1070 m³/s) (Fig. 5), the main channel moved towards the right margin, as shown by the 1969 cadastral maps. This circumstance left a large meander lobe to the left that soon started to be intensively affected by gravel and sand mining. This activity was accompanied by the progressive loss of the other channels. A large surface of depressions and mounds of discarded materials was created. At the same time, a large accumulation of waste on the other side (San Juan de Mozarrifar) was prograding towards the riverbed (Figs. 2e, 3e, 4b). Such waste was produced by nearby metal and paper industries, urban areas, and gravel and sand treatment plants (Marcos González, 1991). As well as causing fluvial contamination, these slag heaps gradually prevented the river from expanding laterally and thus favored an incision on this fluvial section.

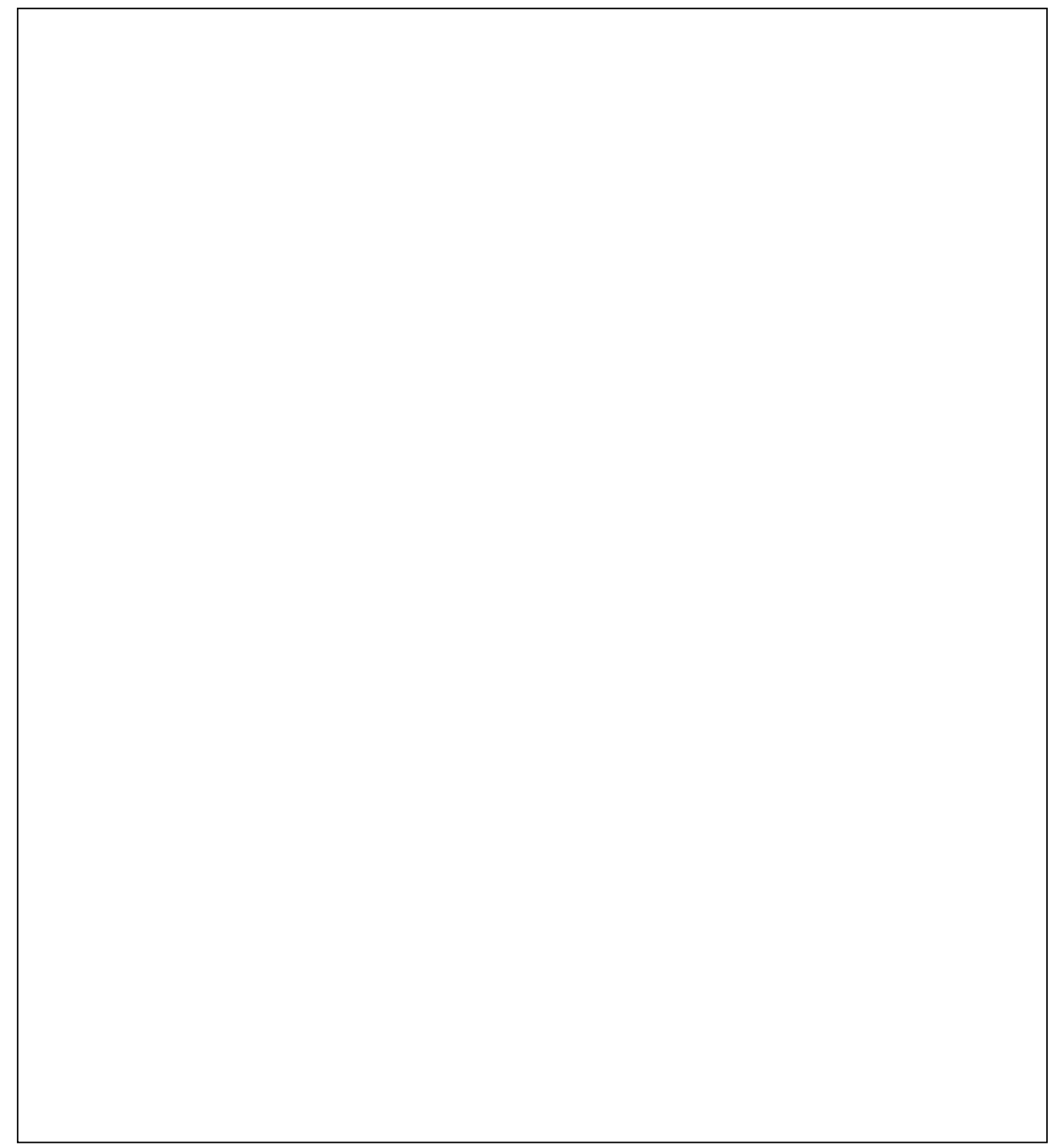

Figure 4. Comparison between the lower Gállego River in the San Juan de Mozarrifar sector between 1927 and 2018. See the changes in the fluvial dynamics, presence of paleodolines, and land use. 


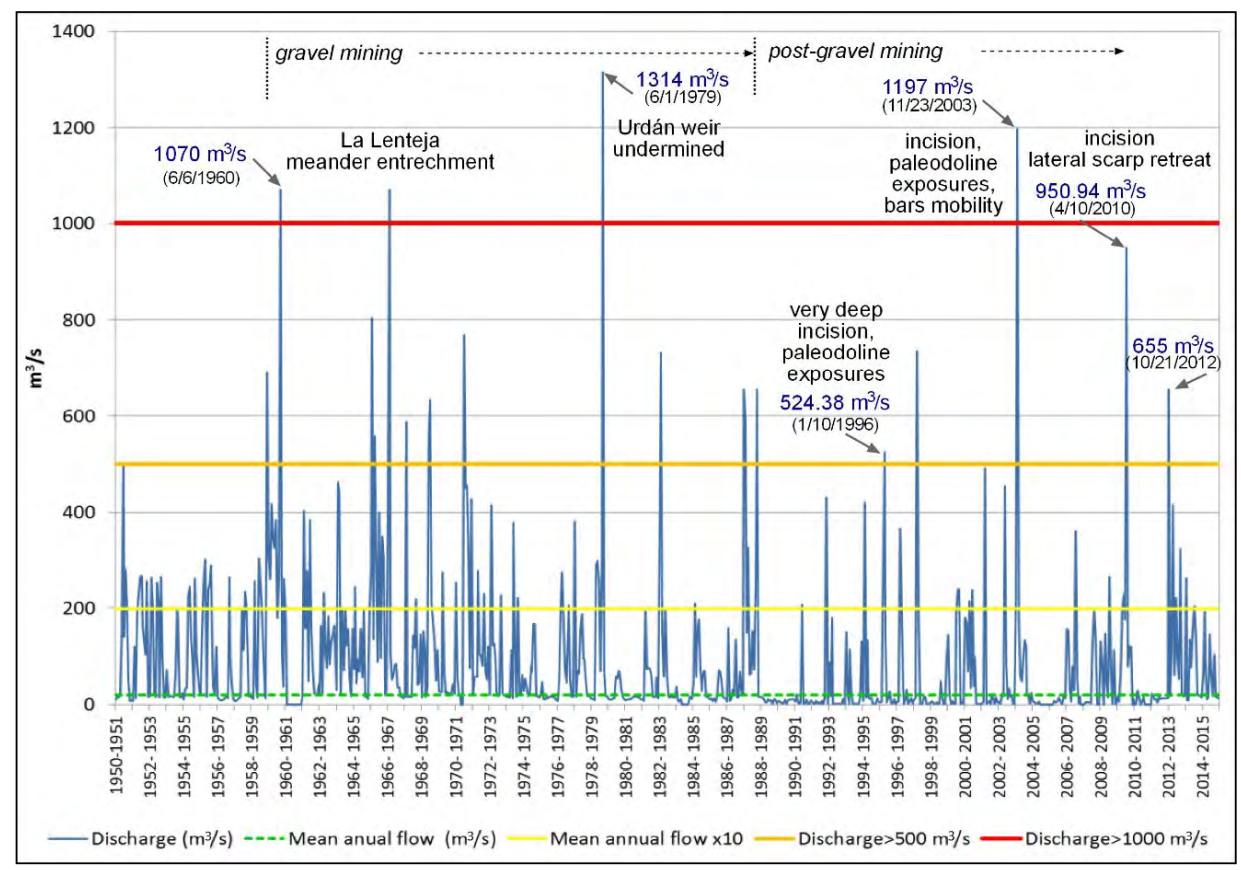

Figure 5. Monthly instantaneous maximum flows of the Gállego River in Ardisa (1950-2015). Flood data and its relationship with geomorphological processes in the lower Gállego River.

Source: Sistema de Información del Anuario de Aforos (https://sig.mapama.gob.es/redesseguimiento/). Ministerio para la Transición Ecológica. Prepared by authors.

\subsection{The incision process and the exhumation of the paleokarstic depressions}

Marcos González (1991) indicates in his river study that in 1989 the incision was $2 \mathrm{~m}$ deep; later, Martín-Vide et al. (2010) estimated 4-5 m of incision depth to the north of San Juan de Mozarrifar, and $6 \mathrm{~m}$ at the foot of the Urdán weir. The incision process continued, and Marqués (2018) estimated that it is around $10 \mathrm{~m}$ downstream from the weir, with a deepening rate of $2.54 \mathrm{~cm} /$ year since 1927. In some sectors of San Juan de Mozarrifar in 2019, the incision surpassed 7-10 m, although it is usually between 5 and $6 \mathrm{~m}$. The incision values should have stabilized when gravel extraction stopped in 1989; however, the incision rate has remained constant since 1927, and Martín-Vide et al. (2010) attributed it to an inertial effect.

As pointed above, the incision produced the exhumation of the paleodolines included on the Qt9 terrace. The first news of this phenomena was published by Ferrando (1907). The paleodolines were exhumed to the north of Villanueva de Gállego, following a flood the previous year, and they contained peat with fossils, among them an Elephas molar. However, no further data about similar findings were reported until January 1996 following another flood $\left(524 \mathrm{~m}^{3} / \mathrm{s}\right.$ ) (Fig. 5). On that occasion, several paleodolines appeared in different sizes and shapes, as well as an Elephas tusk on the gravels of 
Qt9. The abundance of these paleodepressions, especially the number of paleopeats, motivated the studies of these paleolandforms and their later influence on the fluvial dynamics. Many of the first paleodolines were lost to erosion, while new ones emerged in successive floods in 2003, 2010, and 2012 (Fig. 5). According to Gutiérrez et al. (2008), these are sagging sinkholes and collapse dolines, and they affect the evaporitic substrate as well as the covering material. Two main types were morphologically identified: bowlshaped dolines and depressions produced by sudden collapses due to the subsidence of gypsum inner galleries. The latter forms can be funnel-shaped or pit-shaped when the walls are vertical. In addition to simple morphologies, there are also mixed forms combining bowl and funnel-shapes during the final fill.

The bowl-shaped dolines are large and shallow depressions (Fig. 6a) that were partially filled during the floods when fine suspended materials were deposited on them; water remained in some of them during the dry season and led to the development of lagoons with riparian vegetation on the edges and wetland plants inside. Real peats can sometimes be found (Valero et al., 2004). As subsidence continued to be active, the already sedimented layers were deformed on their margins while the next synsedimentary levels were deposited in progressive discordance (Fig. 7a). The final silting was entirely horizontal in contrast to the completely vertical side layers. Small faults and slight subsidence are present but they do not affect the sedimentary body.

The collapse dolines have abrupt margins, smaller diameters, and greater depth than the bowl/shaped dolines. Funnel-shaped dolines have margins with $35^{\circ}$ to $45^{\circ}$ gradients, although successive secondary fractures accompanying the subsidence are often present. The result is an irregular basal profile with narrow funnel-shaped ducts (Fig. 6b). The pit sinkholes have smaller diameter vertical walls and greater depth than the funnel/shaped dolines. All the collapse dolines cause major sediment deformations as they are transferred by subsidence, especially if they have several stages. Accordingly, the fluvial material adaptation is accompanied by folds and faults distorting initial fluvial structures. A vertical arrangement of hardened silt and gravel layers following the collapsed fractures is frequently found (Figs. 6c, 6d, 6e).

The filling of the structures due to collapses does not produce a typical stratigraphy. Each of these dolines exhibits particular deformations so it is impossible to make a generalization. However, in the bowl-shaped dolines, it is possible to establish the sedimentary sequences with relative similarity among them. The following units were identified (Figs. 7a, 7b, 7c):

- Unit 1. Formed of a more then $3 \mathrm{~m}$ thick layer of strongly cemented fluvial gravels that constitutes the base of the depression.

- Unit 2. Composed of $1.20 \mathrm{~m}$ of thick sandy levels, with iron oxide laminations, root marks, and tree trunk molds (Fig. 7d). It has a paleosol with a ferruginous crust on top.

- Unit 3. Composed of lutitic levels and is $4.1 \mathrm{~m}$ thick. It is possible to distinguish two sub-levels: sub-level 3A $(1.1 \mathrm{~m})$ is formed by gray and black marls with abundant gastropods, rhizoconcretions, and conifer trunk fragments of up to 1.3 $\mathrm{m}$ in size, resting in life position (Fig. 7e). The roots of these trunks penetrated up to the base of the next sub-level. The sub-level 3B is located over the organic 
levels of the peat and composed of well-laminated marl layers, typical of a lacustrine environment, and abundant gastropods.

- Unit 4. Discordantly lying over sub-level 3B and some of the preceding units. It is a silty formation of more than $4 \mathrm{~m}$ in thickness. The upper section is unknown because it was affected by the erosive base of the Qt12 terrace (Figs. 7a, 7b).

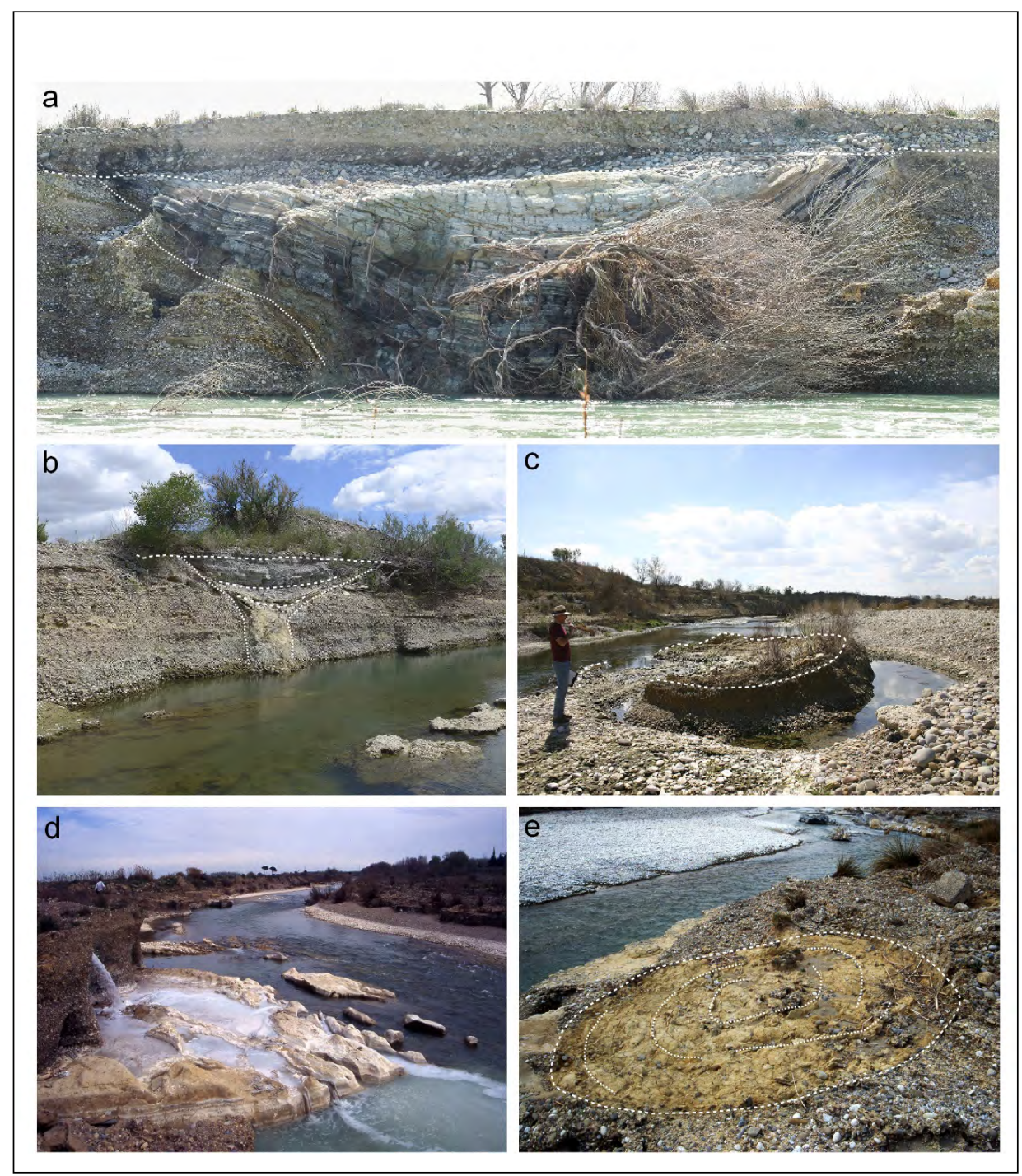

Figure 6. Dolines typology: (a) alluvial bowl-shape doline; (b) funnel-shape doline; (c) pit sinkhole eroded by the river showing the differing resistances of its concentric layers; $(d)$ infill of a bowl-shape doline that has remained prominently in the alluvial bed; $(e)$ concentric layers of deformed material from a pit sinkhole. 


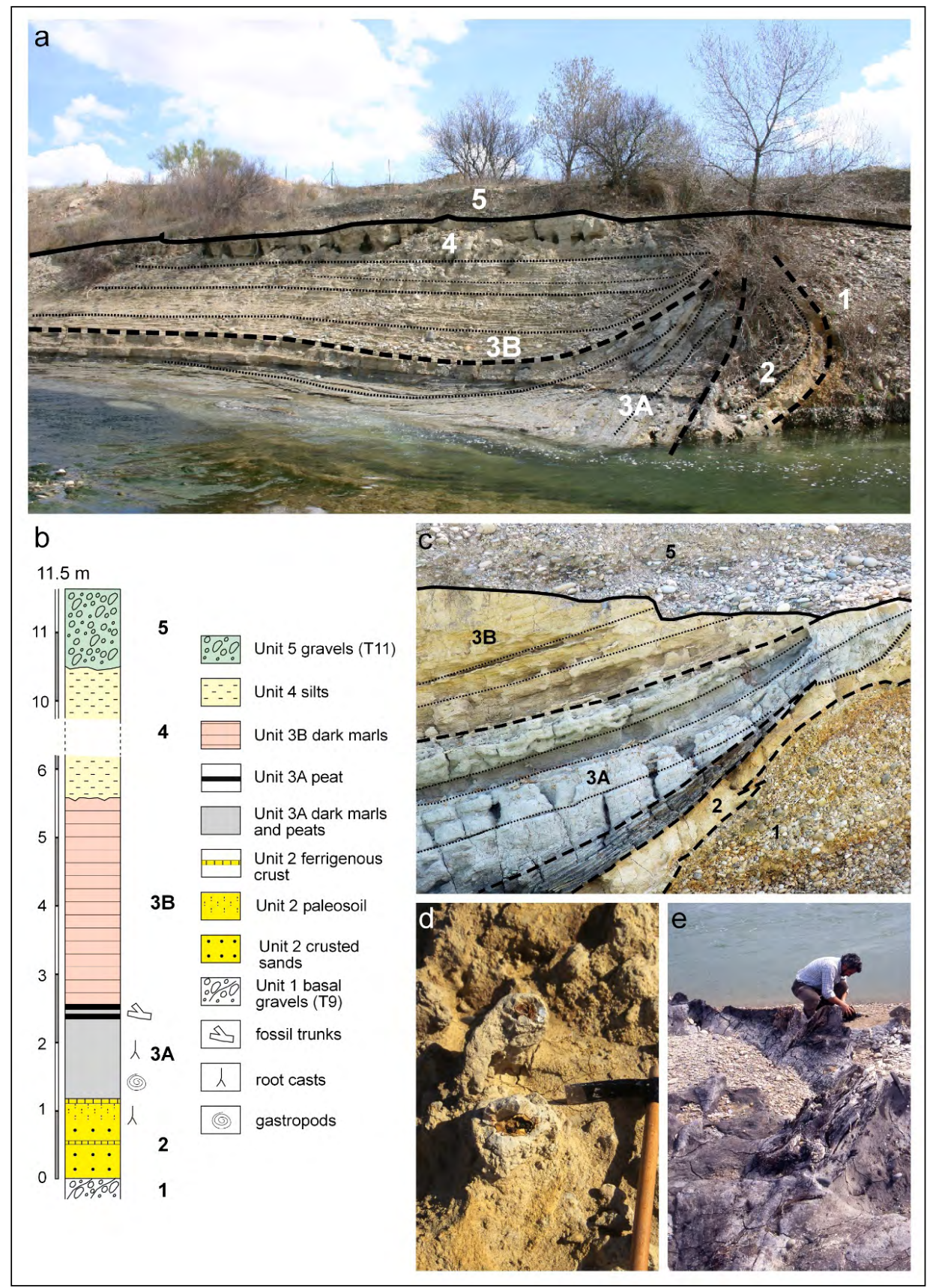

Figure 7. (a), (b), and (c) photographs and stratigraphic profile of one of the bowl-shaped dolines from the San Juan de Mozarrifar area with sedimentary units; (d) detail of the sandy levels with root cast of the Unit 2; (e) peat levels with conifer tree trunks from Unit $3 A$. 
A pollen analysis was performed in one of these sequences (Valero et al., 2004; González-Sampériz, 2015), and the results showed that the environment was arid during formation, as reflected by the high content of xerophytic plants, non-arboreal pollen (NAP) prevailing over the arboreal pollen (AP). It was interpreted as part of a very open steppe landscape of Mediterranean characteristics. The flood periods alternated with dry periods in the floodplain. The flooded doline margins must have been occupied by riparian vegetation, as shown by the presence of trees following the limits of some paleodepressions (Fig. 7e).

\subsection{Geomorphological consequences of the incision process}

The intense degradation suffered by the lower Gállego River between the Urdán weir and the confluence with the Ebro River has led to various kinds of consequences. Although gravel extraction and waste accumulation stopped in the early 1990s, their incidence on the landscape is still evident. It is possible to distinguish gravel mounds, depressions from the older excavations, unstable erodible slopes of waste, superficial subsidence due to the lack of waste homogeneity and slow compaction, riverine contamination, and the remains of constructions related to diverse activities. There has been neither a restoration process nor forestation of these fluvial areas, which would have been necessary because both river sides were converted to walking and leisure routes for people in the city of Zaragoza. Furthermore, the river incision prevented any natural recovery because the aquifer is very low and disconnected from these spaces.

The main consequence of the incision was the exhumation of several karstic paleodepressions, randomly distributed in the interior of the Qt9 terrace (Figs. 4b, 8a). These old morphologies are viewable in the incision walls (Figs. 6a, 8b) as well as in the present fluvial channel (Figs. 6c, 6e, 8c). The linear and lateral erosion is strongly driven by these exhumations composed of highly erodible sediments, surrounded sometimes by very hard and cemented Quaternary conglomerate layers. The filling of these dolines is transported very quickly, forming pools along the fluvial course. In some cases, they reach 3-5 $\mathrm{m}$ in depth with turbulent interior flows. The presence of these pools is evident from an increase in the speed of flow, between 25 and $50 \mathrm{~m}$ upstream, which generates rapids (Fig. 8b) flowing to the depression. Even at times of low water, the pools maintain high levels of water and turbulence and pose risks to swimmers. Drownings are common in the Gállego pools.

The combination of rapids and pools is repeated at several points of the fluvial course and this redirects the river trajectory (Fig. 8a). There are several abrupt direction changes - in some cases reaching $90^{\circ}$ - every time the river encounters one of these depressions (Fig. 8a). These directional changes were not present before the incision (Fig. 3a), when the meanders had less abrupt changes in their trajectories. At present, the river direction is driven by the random levels determined by the exhumation of the paleodolines, although the resulting meanders are apparently similar to the usual meander formation. 


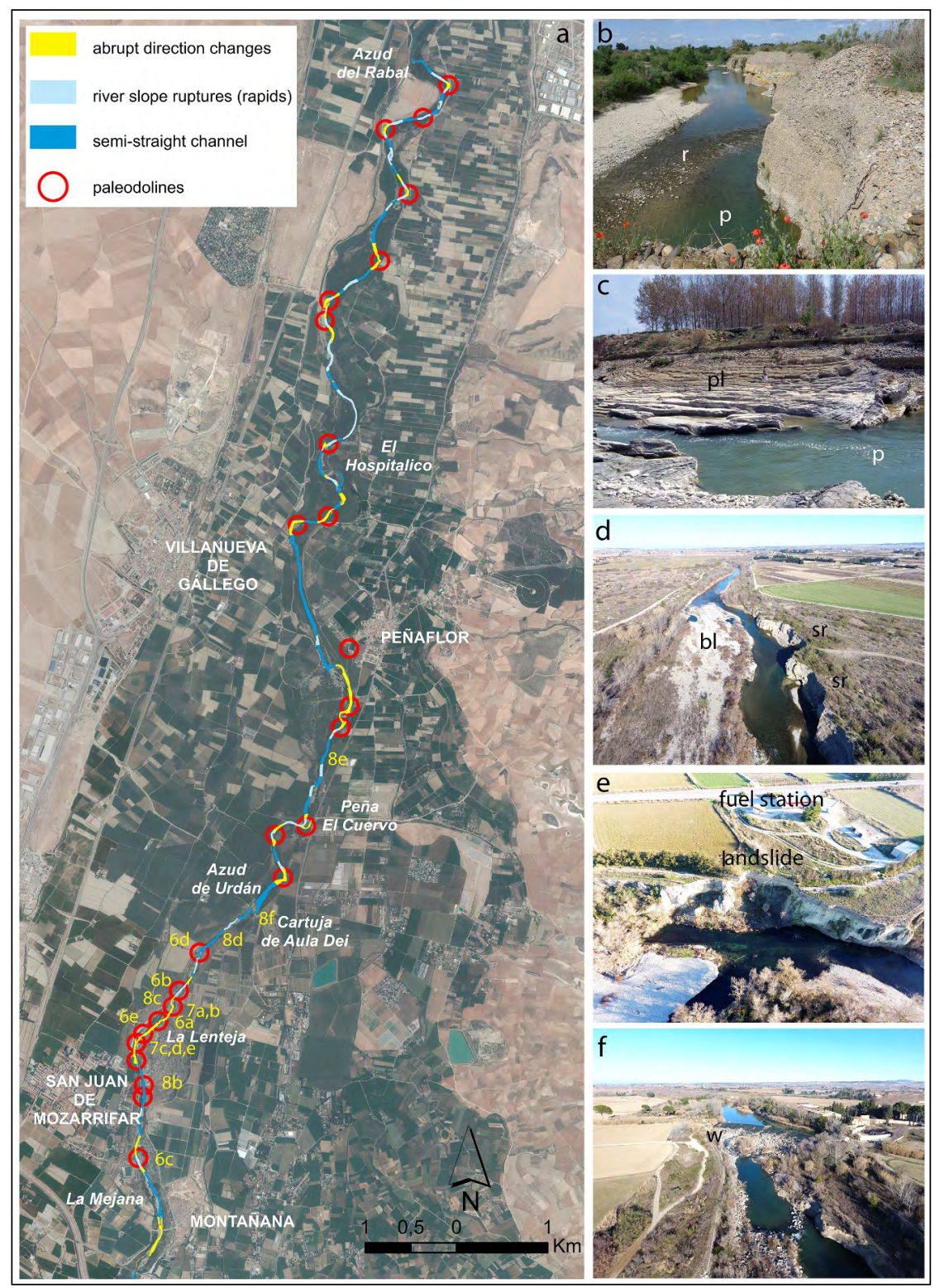

Figure 8. (a) Image from the lower Gállego River (2018) with paleodoline distribution, straight river sections, changes of direction in the river course, and areas with rapids (the yellow numbers indicate the photographs in Figs. 6, 7, and 8); (b) rapids ( $r)$ and pools $(p)$ distribution in relationship with paleodolines to the north of San Juan de Mozarrifar; $(c)$ bowl-shape paleodoline ( $\mathrm{pl}$ ) traversed by river incision and pool area $(p) ;(d)$ incision scarp lateral retreat (rl) by landslides in the left margin and accumulation of lobed and linguoid bars (bl) on the right side, $N$ of La Lenteja; $(f)$ Urdán weir $(w)$ marking the northern limit of the incision. See the concrete blocks reinforcing the weir and the incision start. 
Exhumation of the paleodepressions in the scarped walls of the incision can generate weak points due to the current at the base of the scarps. This process affects the 1-2 basal meters of the scarp and is especially fast when the erosion reaches peats and silts. In this case, the scarps are eroded and form cavities through fluvial abrasion, favoring gravitational and rotational landslides (Figs. 8d, 8e). One good example is a sector near the Peñaflor gas station, where in 2008 there was a steep river scarp, composed of $12 \mathrm{~m}$ of fine sediments and peats from the Qt9 terrace. In the upper section, the scarp included $2 \mathrm{~m}$ of gravel from the Qt10 terrace. In the same year, some cracks affected the road and led to an initial landslide stage, which continued the following years until it developed into a stepped landslide body divided into three sections. The road on the scarp was dragged by the mass movement, and the progressive widening of its crown threatened the gas station itself (Fig. 8e). At present, the displaced mass is protecting the scarp from fluvial erosion, although the risk is latent.

\section{Discussion}

It is clear that the geomorphology of the lower Gállego River has changed and that the river dynamics is very different from the one it had before 1957 (as shown in Fig. 3 ). This change, which started as an incision process in the $1960 \mathrm{~s}$, has accelerated since January 1996.

Different potential causes may have triggered the incision processes in the lower Gállego River, between the Urdán weir and the Ebro confluence. In all cases, the river flow as well as the amount and grain-size of the transported sediments are important variables. It is also necessary to consider the reservoirs built in the basin - Búbal in the upper course with a capacity of $64 \mathrm{hm}^{3}$ (built in 1971); La Peña in the middle course with a capacity of $5.3 \mathrm{hm}^{3}$ (1913); Ardisa at the start of the lower course with a capacity of $25 \mathrm{hm}^{3}$ (1932). These structures implied ruptures in the fluvial dynamics, which could potentiate the incision process as a result of sediment retention, flood regulation, and flow loss for irrigation, as pointed out by Williams and Wolman (1984), Kondolf (1997), Brandt (2000), and Batalla et al. (2004). Other civil works also produced water deviations, including weirs to feed irrigation ditches (such as the Camarera, del Raval, and Urdán ditches). In the Pyrenean area, a strong recovery of vegetated areas previously used for agriculture has occurred in recent decades. This recovery together with reforestation has influenced the river flows (García-Ruiz et al., 2001) and the volume of suspended fine sediments in the main load (García-Ruiz and Ortigosa, 1988; Rubio and HernándezSantón, 1990; Martínez-Castroviejo et al., 1991). These changes imply a great difference from previous dynamics, when secular deforestation in Pyrenean basins, as well as other Mediterranean areas (Bravard, 1994), caused an increase in the sedimentary river loads - especially of fine sediments (Peña Monné et al., 2004). This process led to large accumulations in valleys and coastal plains. However, as already discussed by MartínVide et al. (2010), these factors do not seem to have influenced the lower Gállego because they were already at work before the incision started. If these processes were influencing the Gállego River, they might have generated the same incision response upstream of the Urdán weir (currently unaffected by the incision process). 
The use of the river courses for gravel mining may also trigger incision processes. Lagasse et al. (1980), Erskine et al. (1985), Kondolf (1994, 1997), Brown et al. (1998) and Rinaldi et al. (2005) have shown that some geomorphological effects favor incision. Among them, they cite sediment deficit, rupture of the equilibrium between sediment supply and transport capacity, riverbed armoring, loss of lateral channel mobility with a tendency to develop one straight and unstable channel, and upstream and downstream erosion. The same effects have been described for the rivers in NE Spain (Batalla, 2003; Rovira et al., 2005; Tuset et al., 2015; Béjar et al., 2018; Muñoz-Narciso et al., 2018) and by Martín-Vide et al. (2010) for the lower Gállego. Other effects have been mentioned for flora and fauna and water quality in general, both during gravel mining and after this activity ceased (Meador and Layher, 1998; Buendía et al., 2011; Jones et al., 2012; Béjar et al., 2017). Gravel extraction in the Gállego River has been considered the trigger factor for the incision process (Martín-Vide et al., 2010). Using data from gravel extraction permits granted by the Confederación Hidrográfica del Ebro, these authors estimated that about one million $\mathrm{m}^{3}$ of gravel was extracted between 1963 and 1989. The effect of such extraction, together with the progressive channel narrowing caused by the lateral waste, could explain the magnitude of the incision and the river channelization.

There is no doubt that gravel extraction triggered the incision. However, we do not know the extraction rate during those years because the amount extracted usually doubled the amount officially allowed. Therefore, an estimation of the volumes of extracted and eroded gravel would be unrealistic. Béjar et al. (2018) analyzed the mining effects on the riverbed during gravel mining in another Pyrenean river (the Cinca River) and found that the sediment volume transported downstream was similar to that generated by a flood and smaller in the case of solid lode. They also indicated that these mining activities affect up to $1.5 \mathrm{~km}$ downstream. In fact, although some of the lower Gállego mines are very close to the Ebro River confluence (Santa Isabel sector), the merging area was unaffected by sediment deposits and incision. It has been verified that gravel bars are generated during floods at short distances upstream (Peñaflor-Peña del Cuervo) and downstream from the Urdán weir, and all the gravel comes from the erosion of the Quaternary substrate riverbed and the riverside (Peña-Monné et al., 2011). Thus, much of the gravel in these bars contains fragments of the original Quaternary conglomerate cement. It is also frequent to find pieces of peat from the karstic filling included in the bars.

This constant supply, whose mobility is appreciable after each flood, would be enough to quickly minimize the gravel extraction effect and so end the incision process and perhaps begin some aggradation. Much of the sediment has a very short trajectory in response to the concentration of energy in certain sectors. Pools are formed due to the existence of obstacles in the channel (vegetation, traversed trunks, and hard substrate layers) and these generate concentrations of turbulence with the digging of pools followed downstream from the formation of linguoid and lobed bars that overlap in successive phases (Fig. 8d) (Peña-Monné et al., 2011). There is no regularity in the process activation, and we noted that there was no coincidence between the areas where the largest extractions of sand and gravel were made (Santa Isabel, Montañana) and the sections where the highest incision rates were recorded (upstream San Juan de 
Mozarrifar). Finally, another weak point for the simple explanation of incision by gravel extraction is the continuity and even progression of the incision despite the end of gravel mining in 1989 (Fig. 5).

We believe that gravel mining was substantial at the beginning of the 1960s and that it generated the first part of the incision affecting the first two meters of the Qt12 terrace. This value might have been constant in some sections, or might even have been higher in some places, if the substrate had been homogeneous, but in this case, the substrate was formed by the underlying Qt9 terrace. This is an old deposit, which is highly encrusted in its gravel levels, as shown in Unit 1, Figure 7b. These resistant levels contrast with the interbedded paleodolines composed of silts and peats. These cause areas with faster erosion in the river channel, in contrast to other areas formed by Quaternary residual sandstone and conglomerates (Fig. 6c), which form resistant rocky riverbeds.

The upstream erosion of the rapids facilitates the formation of a new longitudinal river profile that reaches the deepened position of the pool channel. This upstream action is stopped by the Urdán weir, where the incision is more than $10 \mathrm{~m}$ deep. At this point, the profile has a knickpoint reinforced by the presence of the weir. Thus, the high incision value in this place is the result of a mixed action involving upstream erosion and the basal undermining at the front of the weir. After the flood of June $1^{\text {st }}$, 1979, with a flow of $1314 \mathrm{~m}^{3} / \mathrm{s}$ (Fig. 5), the base of the weir was reinforced with concrete blocks. These still play a protective role (Fig. 8f) although many have been transported several kilometers downstream.

It is also important to consider that in the floods (2003, 2010, 2012, Fig. 5) following the initial incision process, lateral erosion processes occurred as a result of the lateral paleodoline exhumation. Some were even upstream of the Urdán weir and caused landslides (Fig. 8c), such as that of Peñaflor (Fig. 8d). This process is currently evolving in some areas with the formation of widened riverbeds and the development of a new riverbed. The new level is being progressively widened (Qt13) and leaving the old Qt12 riverbed in an isolated position. At present, Qt12 is an independent terrace, non-existent in other rivers in the region. The Qt12 terrace has an upper age estimated at the 1960s-70s because it contains eroded pieces of bricks, slag castings, tiles, etc. This unusual consequence is an example of anthropically triggered geomorphological evolution with unpredictable later evolution that we can frame in the context of the Anthropocene.

\section{Conclusions}

A multi-temporal analysis of the lower Gállego River enabled us to establish the major changes experienced by its course and dynamics in the period between 1927 and 2018. These changes were first triggered by human activity, especially in the 1960 s as a consequence of the development of the city of Zaragoza. Gravel mining from the riverbed and the accumulation of large volumes of waste on its banks changed a wide braided river into a channelized river with low sinuosity, which triggered a considerable incision process. 
This process was started by human activities. However, since the 1990s and the cessation of human interventions on the fluvial course, the river dynamics have been complemented, and even driven in some sections, by a new factor. The incision reached the underlying Qt9 terrace, exhuming paleodolines filled with easily eroded sediments, thus creating discontinuities in riverbed resistance. This led to the creation of pools and resistant sections of old encrusted gravel. The high incision rates and continuity of the process after gravel mining ended might be the direct consequence of the advance in the exhumation process. Moreover, dolines are directing the present river course and causing abrupt changes in its direction, creating incision scarps.

The future evolution of the fluvial dynamics is then related to the continuity of paleodoline exhumation in the riverbed and sides. This will lead to the widening and formation of a new riverbed (Qt13) - as well as the abandonment (even during floods) of the riverbed from the 1960s, which will become an independent new terrace (Qt12). This process is exceptional in the NE of Spain because the Gállego River has one more terrace than the other rivers in the region.

\section{Acknowledgements}

While writing this paper one of the members of our team (Dr. Carlos Sancho Marcén) suddenly died, we finished it on his memory. We thank to Mr. Manuel Arnal Lizarraga of the Confederación Hidrográfica del Ebro for his help on data searching. This work is a contribution of the "Primeros Pobladores del Valle del Ebro" research group (Government of Aragon and European Social Fund) and fits within the research scope of IUCA (Environmental Sciences Institute of the University of Zaragoza). Grants PIUNT G629 (Universidad Nacional de Tucumán), PIP 837 (CONICET) and PICT 2018-1119 (ANPCyT).

\section{References}

Alberto, F., Gutiérrez, M., Ibáñez, M.J., Machín, J., Peña, J.L., Pocovi, M., Rodríguez, J. 1984. El Cuaternario de la Depresión del Ebro en la región aragonesa. Cartografía y síntesis de los conocimientos existentes. Universidad de Zaragoza y Estación Experimental Aula Dei: Zaragoza, $217 \mathrm{pp}$.

Batalla, R.J. 2003. Sediment deficit in rivers caused by dams and instream gravel mining. A review with examples from NE Spain. Cuaternario y Geomorfología 17 (3-4), 79-91.

Batalla, R.J., Gómez, C.M., Kondolf, G.M. 2004. Reservoir-induced hydrological changes in the Ebro River basin (NE Spain). Journal of Hydrology 290, 117-136. https://doi.org/10.1016/j. jhydrol.2003.12.002.

Béjar, M., Vericat, D., Nogales, I., Gallart, F., Villanueva, R.J.B. 2018. Efectos de las extracciones de áridos sobre el transporte de sedimentos en suspensión en ríos de montaña (alto río Cinca, Pirineo central). Cuadernos de Investigación Geográfica 44 (2), 641-658. https://doi. org/10.18172/cig.3256.

Benito, G. 1989. Geomorfología de la cuenca baja del río Gállego. PhD thesis, Zaragoza University, Zaragoza.

Benito, G., Gutiérrez, F., Pérez-González, A., Machado, M.J. 2000. Geomorphological and sedimentological features in Quaternary fluvial systems affected by solution-induced 
subsidence (Ebro basin, NE-Spain). Geomorphology 33, 209-224. https://doi.org/10.1016/ S0169-555X(99)00124-5.

Benito, G., Sancho, C., Peña, J.L., Machado, M.J., Rhodes, E.J. 2010. Large-scale karst subsidence and accelerated fluvial aggradation during MIS6 in NE Spain: Climate and pleohydrological implications. Quaternary Science Reviews 29, 2694-2704. https://doi.org/10.1016/j. quascirev.2010.06.020.

Benito, G., Gutiérrez, F., Machado, M.J., Pérez-González, A., Pérez-López, A. 1996. Modelo morfo-sedimentario de evolución fluvial cuaternaria en condiciones de subsidencia kárstica de evaporitas (río Gállego, cuenca del Ebro). Cuadernos de Geología Ibérica 21, 395-420.

Benito, G., Pérez-González, A., Gutiérrez, F., Machado, M.J. 1998. River response to Quaternary subsidence due to evaporite solution (Gállego River, Ebro basin, Spain). Geomorphology 22, 243-263. https://doi.org/10.1016/S0169-555X(97)00088-3.

Bomer, B. 1957. Les terrasses du Gállego. Livret-guide de l'excursion N1 Pyrénées. V Congrés International INQUA. Madrid-Barcelona, pp. 93-99.

Bomer B. 1978. Le Bassin de l'Ebre et ses bordures montagneuses. Étude géomorphologique. PhD thesis, Université de Caën: France.

Bravard, J.P. 1994. L'incision des lits fluviaux: du phénomène morphodynamique natural et réversible aux impacts irreversibles. Revue de Géographie de Lyon 69 (1), 5-10.

Brown, A.V., Lyttle, M.M., Brown, K.B. 1998. Impacts of gravel mining on gravel bed streams. Transactions of the American Fisheries Society 127, 979-994. https://doi.org/10.1577/15488659(1998) 127<0979:IOGMOG>2.0.CO;2.

Buendia, C., Gibbins, C.N., Vericat, D., Lopez-Tarazon, J.A., Batalla, R.J. 2011. Influence of naturally high fine sediment loads on aquatic insect larvae in a montane river. Scottish Geographical Journal 127, 315-334. https://doi.org/10.1080/14702541.2012.670006.

Cuadrat, J.M. 2004. El clima de Aragón. In: J.L. Peña Monné, L.A. Longares, M. Sánchez (Eds.), Geografía Física de Aragón. Aspectos generales y temáticos. Instución Fernando el Católico, Universidad de Zaragoza, Zaragoza, pp. 15-26.

Erskine, W.D., Geary, P.M., Outhet, D.N. 1985. Potential impact of sand and gravel extraction on the Hunter River, New South Wales. Australian Geographical Studies 23, 71-86. https://doi. org/10.1111/j.1467-8470.1985.tb00479.x.

Ferrando, P. 1907. El turbal de Villanueva del Gállego. Boletín de la Sociedad Española de Historia Natural 9, 79-80.

García-Anquela, J.A., Tena, J.M., Mandado, J.A. 1985. La explotación de áridos como factor modificador de los cauces fluviales naturales. Cuadernos de Investigación Geográfica 11, 83-89. https://doi.org/10.18172/cig.945.

Garcia-Castellanos, D., Vergés, J., Gaspar-Escribano, J., Cloetingh, S. 2003. Interplay between tectonics, climate, and fluvial transport during the Cenozoic evolution of the Ebro Basin (NE Iberia). Journal of Geophysical Research 108 (B7), 2347. https://doi. org/10.1029/2002jb002073.

García-Ruiz, J.M., Beguería, S., López-Moreno, J.I., Lorente, A., Seeger, M. 2001. Los recursos hídricos superficiales del Pirineo Aragonés y su evolución reciente. Geoforma, Logroño, $192 \mathrm{pp}$.

González-Sampériz, P. 2015. San Juan de Mozarrifar, Río Gállego, Zaragoza. In J. Carrión (Ed.), Cinco millones de años de cambio florístico y vegetal en la Península Ibérica e Islas Baleares, Murcia (Spain). Ministerio de Economía y Competitividad, Madrid,pp. 210-212.

Guerrero, J., Gutiérrez, F., Galve, J. 2013. Large depressions, thickened terraces and gravitational deformation in the Ebro River valley (Zaragoza area, NE Spain): Evidence of glauberite and halite interstratal karstification. Geomorphology 196, 162-176. https://doi.org/10.1016/j. geomorph.2012.06.024. 
Guerrero, J., Gutiérrez, F., Lucha, P. 2004. Paleosubsidence and active subsidence due to evaporite dissolution in the Zaragoza area (Huerva River valley, NE Spain): processes, spatial distribution and protection measures for transport routes. Engineering Geology 72 (3-4), 309329. http://doi.org/10.1016/j.enggeo.2003.10.002.

Guerrero,J.,Gutiérrez,F.,Lucha,P.2008. Impact of halite dissolution subsidence on Quaternary fluvial terrace development: Case study of the Huerva River, Ebro Basin, NE Spain. Geomorphology 100 (1-2), 164-179. https://doi.org/10.1016/j.geomorph.2007.04.040.

Gutiérrez, F., Calaforra, J.M., Cardona, F., Ortí, F., Durán, J.J., Garay, P. 2008. Geological and environmental implications of the evaporate karst in Spain. Environmental Geology 53, 951965. https://doi.org/10.1007/s00254-007-0721-y.

Gutiérrez, F., Guerrero, J., Lucha, P. 2008. Quantitative sinkhole hazard assessment. A case study from the Ebro Valley evaporite alluvial karst (NE Spain). Natural Hazards 45, 211-233. https://doi.org/10.1007/s11069-007-9161-y.

Gutiérrez, F., Guerrero, J., Lucha, P. 2008. A genetic classification of sinkholes illustrated from evaporite paleokarst exposures in Spain. Environmental Geology 53 (5), 993-1006. https:// doi.org/10.1007/s00254-007-0727-5.

Guttiérez, M., Ibanez, M.J., Peña,J.L., Rodríguez, J., Soriano, M.A. 1985. Quelques exemples de karst sur gypse dans la Depression de l'Ebre. Karstologie 6, 29-36. http://doi.org/10.3406/karst.1985.2102

Gutiérrez, M., Peña Monné, J.L. 1994. Depresión del Ebro. In: M. Gutiérrez Elorza (Ed.), Geomorfología de España. Rueda, Madrid, pp. 305-349.

Gutiérrez, M., Peña Monné, J.L., Sánchez, M. 1985. Dolinas aluviales en los materiales yesíferos de Villalba Baja (Teruel). Actas I Reuniao do Quaternario Ibérico, Lisboa, II, pp. 427-438.

Jones, J.I., Murphy, J.F., Collins, A.L., Sear, D.A., Naden, P.S., Armitage, P.D. 2012. The impact of fine sediment on macro-invertebrates. River Research and Applications 28, 1055-1071. https://doi.org/10.1002/rra.1516.

Kondolf, G.M. 1994. Geomorphic and environmental effects of instream gravel mining. Landscape and Urban Planning 28, 225-243. https://doi.org/10.1016/0169-2046(94)90010-8.

Kondolf, G.M. 1997. Hungry water: effects of dams and gravel mining on river channels. Environmental Management 21 (4), 533-551. https://doi.org/10.1007/s002679900048.

Lagasse, P.F., Winkley, B.R., Simons, D.B. 1980. Impact of gravel mining and river system stability. Journal of the Waterways, Port, Coastal and Ocean Division 106 (3), 389-404.

Lamelas, M.T. 2007. Geo-resources and geo-hazards in the context of a sustainable development in the periphery of urban areas, exemplary of a part of the Ebro Basin in the surroundings of Zaragoza (Spain). PhD thesis, Darmstadt University: Germany.

Lewis, C.J., McDonald, E.V., Sancho, C., Peña, J.L., Rhodes, E.J. 2009. Climatic implications of correlated Upper Pleistocene glacial and fluvial deposits on the Cinca and Gállego Rivers, NE Spain. Global and Planetary Change 67, 141-152. https://doi.org/10.1016/j. gloplacha.2009.01.001.

Luzón, A., Pérez, A., Soriano, M.A., Pocoví, A. 2008. Sedimentary record of Pleistocene paleodoline evolution in the Ebro basin (NE Spain). Sedimentary Geology 205, 1-13. https:// doi.org/10.1016/j.sedgeo.2008.01.004.

Marcos González, A. 1991. Análisis de la evolución reciente de la morfología del cauce del Bajo Gállego en las proximidades de Zaragoza: influencia de las actuaciones humanas en su entorno. Acta Geoógica. Hispánica 26 (1), 23-33.

Marqués, L.A. 2018. Alteraciones hidrogeomorfológicas en el Bajo Gállego a partir del registro instrumental. $\mathrm{PhD}$ thesis, Zaragoza University, Spain.

Martín-Vide, J.P., Ferrer-Boix, C., Ollero, A. 2010. Incision due to gravel mining: Modeling a case study from the Gállego River, Spain. Geomorphology 117, 261-271. https://doi. org/10.1016/j.geomorph.2009.01.019. 
Martínez-Castroviejo, R., Gómez-Villar, A., García-Ruiz, J.M. 1991. Ajustes fluviales derivados de usos del suelo en el Pirineo aragonés. Cuaternario y Geomorfología 5, 91-105.

Meador, M.R., Layher, A.O. 1998. Instream sand and gravel mining. Environmental issues and regulatory process in the United States. Fisheries 23 (11), 6-13. https://doi.org/10.1577/15488446(1998)023<0006:isagm>2.0.co;2.

Mensua, S., Ibáñez, M.J. 1977. Sector Central de la Depresión del Ebro. Mapa de terrazas fluviales y glacis. Zaragoza. III Reunión Nacional de Geomorfología. Universidad de Zaragoza, Zaragoza, pp. 1-18.

Muñoz-Narciso, E., Vericat, D., Francke, T., Batalla, R.J. 2018. Cambios morfológicos (1956-2012) en un río de gravas afectado por múltiples impactos antrópicos (Río Cinca, Pirineos Centrales). In: C. García, L. Gómez-Pujol, E. Morán-Tejeda (Eds.), Geomorfología del Antropoceno. Efectos del cambio global sobre los procesos geomorfológicos. Universitat Illes Balears, Sociedad Española de Geomorfología, Palma de Mallorca, pp. 253-256.

Ortí, F. 1990. Introducción a las evaporitas de la Cuenca Terciaria del Ebro. In: F. Ortí, R.J. Salvany (Eds.), Formaciones evaporíticas de la Cuenca del Ebro y cadenas periféricas y de la zona de Levante. ENRESA-GPPG, Barcelona, pp. 62-66.

Ortí, F., Salvany, J.M., Rosell, L.A., Inglès, M. 1989. Sistemas lacustres evaporíticos del Terciario de la Cuenca del Ebro. Geogaceta 6, 103-104.

Pardo, G., Arenas, C., González, A., Luzón, A., Muñoz, A., Pérez, A., Pérez-Rivarés, F.J., Vázquez-Urbez, M., Villena, J. 2004. La cuenca del Ebro. In: J.A. Vera (Ed.), Geología de España. IGME and Sociedad Geológica de España, Madrid, pp. 533-543.

Peña Monné, J.L. 2018. Geoarqueología aplicada a la reconstrucción paleoambiental: La evolución del Holoceno superior en el NE de España. Boletín Geológico y Minero 129 (1/2), 285-303. https://doi.org/10.21701/bolgeomin.129.1.011.

Peña Monné, J.L., Sancho Marcén, C., Rhodes, E., Lewis, C., McDonald, E. 2003. Las morrenas terminales de los valles glaciares del Gállego y Cinca (Pirineos de Huesca). Datos cronológicos. Boletín Glaciológico Aragonés 4, 91-109.

Peña, J.L., Sancho, C., Lewis, C., McDonald, E., Rhodes, E. 2004. Datos cronológicos de las morrenas terminales del glaciar del Gállego y su relación con las terrazas fluvioglaciares (Pirineo de Huesca). In: J.L. Peña Monné, L.A. Longares, M. Sánchez (Eds.), Geografía Física de Aragón: Aspectos generales y temáticos. Universidad de Zaragoza e Instución Fernando el Católico, Zaragoza, pp. 71-84.

Peña Monné, J.L., Marcén, C.S., Jiménez, A.M., Orrios, A.C. 2014. Clima y hombre en la evolución de las vales del sector central de la Depresión del Ebro durante el Holoceno superior. In: J. Arnáez, P. González-Sampériz, T. Lasanta, B.L. Valero-Garcés (Eds.), Geoecología, cambio ambiental y paisaje: homenaje al Profesor José María García Ruiz. Instituto Pirenaico de Ecología (CSIC), Universidad de La Rioja, pp. 91-102.

Quirantes, J. 1978. Estudio sedimentológico y estratigráfico del Terciario continental de los Monegros. Institución Fernando el Católico, Zaragoza.

Rinaldi, M., Wyżga, B., Surian, N. 2005. Sediment mining in alluvial channels: physical effects and management perspectives. River Research and Applications 21, 805-828. https://doi. org/10.1002/rra.884.

Rovira, A., Batalla, R.J., Sala, M. 2005. Response of a river sediment budget after historical gravel mining (the lower Tordera, NE Spain). River Research and Applications 21 (7), 829-847. https://doi.org/10.1002/rra.885.

Rubio, V., Hernández-Santón, C. 1990. La evolución reciente del cauce del río Ara. Cuadernos de Investigación Geográfica 16 (1-2), 99-108. http://dx.doi.org/10.18172/cig.987. 
Salvany, J.M., García-Veigas, J., Ortí, F. 2007. Glauberite-halite association of the Zaragoza Gypsum Formation (Lower Miocene, Ebro Basin, NE Spain). Sedimentology 54, 443-467. https://doi.org/10.1111/j.1365-3091.2006.00844.x.

Sancho, C., Peña, J.L., Lewis, C., McDonald, E., Rhodes, E. 2004. Registros fluviales y glaciares cuaternarios de las cuencas de los ríos Cinca y Gállego (Pirineos y Depresión del Ebro). In: F. Colombo, C.L. Liesa, G. Meléndez, A. Pocoví, C. Sancho, A.R. Soria (Eds.), Geo-Guías 1. Itinerarios Geológicos por Aragón. Sociedad Geológica de España, Madrid, pp. 181-205.

Sancho, C., Peña, J.L., Lewis, C., McDonald, E., Rhodes, E. 2008. Actividad glaciar y desarrollo de terrazas durante el Pleistoceno superior en Pirineos-Cuenca del Ebro. Geo-Temas 10, 763 766.

Simón, J.L., Soriano, M.A. 2002. Actual and potential doline subsidence hazard mapping: case study in the Ebro basin (Spain). In: P.T. Bobrowsky (Ed.), Geoenvironmental Mapping: Method, Theory and Practice. Balkema, Rotterdam, pp. 649-666.

Soriano, M.A., Luzón, A., Yuste, A. 2012. Quaternary alluvial sinkholes: Record of environmental conditions of karst development, examples from the Ebro Basin, Spain. Journal of Cave and Karst Studies 74 (2), 173-185. https://doi.org/10-4311/2011JCKS0201.

Soriano, M.A., Simón, J.L. 1995. Alluvial dolines in the central Ebro basin, Spain: a spatial and developmental hazard analysis. Geomorphology 11, 295-330. https://doi.org/10.1016/0169$555 x(94) 00066-z$.

Torrescusa, S., Klimowitz, J. 1990. Contribución al conocimiento de las evaporitas miocenas (Fm. Zaragoza) de la Cuenca del Ebro. In: F. Ortí, J.M. Salvany (Eds.), Formaciones evaporíticas de la Cuenca del Ebro y cadenas periféricas y de la zona de Levante. ENRESA-GPPG, Barcelona, pp. 120-122.

Tuset, J., Vericat, D., Batalla, R.J. 2015. Evolución morfo-sedimentaria del tramo medio del río Segre. Cuadernos de Investigación Geográfica 41 (1), 23-62. https://10.18172/cig.2707.

Urgeles, R., Camerlenghi, A., Garcia-Castellanos, D., De Mol, B., Garcés, M., Vergés, J., Haslamk, I., Hardmank, M. 2010. New constraints on the Messinian sea level draw down from 3D seismic data of the Ebro Margin, western Mediterranean. Basin Research 23 (2), 123-145. https://doi.org/10.1111/j.1365-2117.2010.00477.x.

Valero-Garcés, B., González-Sampériz, P., Navas, A., Machín, J., Delgado-Huertas, A., PeñaMonné, J.L., Sancho-Marcén, C., Stevenson, T., Davis, B. 2004. Paleohydrological fluctuations and steppe vegetation during the last glacial maximum in the central Ebro valley (NE Spain). Quaternary International 122 (1), 43-55. https://doi.org/10.1016/j. quaint.2004.01.030.

Williams, G.P., Wolman, M.G. 1984. Downstream effects of dams on alluvial rivers. US Geological Survey Professional Paper 1286, 83. https://doi.org/10.1002/rrr.3450010210. 